\section{Bermudagrass Growth in Soil Supplemented with Inorganic Amendments}

\author{
Glenn R. Wehtje ${ }^{1}$, Joey N. Shaw ${ }^{2}$, Robert H. Walker ${ }^{3}$, and \\ Walker Williams ${ }^{4}$ \\ Department of Agronomy and Soils, Auburn University, Auburn University, \\ AL 36849
}

\begin{abstract}
Additional index words. Cynodon dactylon $\mathrm{x}$ C. transvaalensis, extractable water, soil oxygen, soil bulk density, zeolites, porous ceramics, diatomaceous earths, peat, drought tolerance
\end{abstract}

\begin{abstract}
Various inorganic soil amendments have been promoted as a means of improving the chemical and physical properties of certain soils. To test this hypothesis, a marginally productive soil was supplemented with $20 \%, 40 \%, 60 \%$, and $80 \%$ (v/v) of either selected inorganic amendments or sand. Amendments consisted of commercially available diatomaceous earth, calcined clay, zeolite, and crystalline $\mathrm{SiO}_{2}$. The soil material was extracted from the argillic horizon of a Cecil sandy loam (fine, kaolinitic, thermic Typic Kanhapludults). Ability of these soil-amendment mixtures to promote 'Tifway' bermudagrass [Cynodon dactylon (L.) Pers. $x$ C. transvaalensis Burtt Davy] growth was evaluated under greenhouse conditions, and contrasted to that obtained in nonamended soil. Selected chemical and physical properties that are pertinent to plant growth were also evaluated. The experiment, which was conducted $3 \times$, began with $a \approx 60$-day period in which both water and nutrients were optimum. This was followed by a 30-day drought. During optimum water and nutrients, no soil-amendment treatment(s) consistently resulted in superior bermudagrass growth compared to soil alone. However, $<2 \%$ of the bermudagrass tissue that was produced during the drought became green and succulent with the resumption of irrigation in nonamended soil. This percentage was exceeded by all treatments that contained either $\geq 60 \%$ diatomaceous earth (Axis), or $\geq 40 \%$ calcined clay (Profile); and by $100 \%$ zeolite (Clinolite) and $100 \%$ silica (Green's Choice). Drought-sustaining ability of soil-amendment mixtures was significantly $(P<0.05)$ correlated with water-holding ability, soil strength, bulk density, and oxygen diffusion rate, but not correlated with either pH or cation exchange capacity (CEC). While certain inorganic amendments did improve the drought-sustaining ability of soil, the amount required was generally $\geq 40 \%$.
\end{abstract}

The rooting zone of most modern golf course putting greens, including those that meet United States Golf Association (USGA) specifications (USGA Greens Section Staff, 1993), are constructed by replacing the existing soil with sand that has been mixed with a relatively small amount of organic material, typically peat (Kussow, 1987; USGA Greens Section Staff, 1993). However, some greens are formed by simply shaping the existing soil on the site to the desired contours, possibly incorporating organic matter, such as peat moss, and planting the desired turf species. This type of putting green, termed a push-up green, is less expensive to install but is susceptible to soil compaction (Christians, 1998). Soil compaction in a push-up green can be alleviated by incorporating sand into the surface and/or core aerification, in which case the core holes are back-filled with sand. Unfortunately, these practices often only alleviate compaction temporarily (Christians, 1998).

Received for publication 6 May 2002. Accepted for publication 8 Dec. 2002. Research was supported by Alabama Agricultural Experiment Station.

${ }^{1}$ Professor; to whom reprint requests should be sent.

E-mail address: gwehtje@acesag.auburn.edu

${ }^{2}$ Assistant Professor.

${ }^{3}$ Professor.

${ }^{4}$ Graduate Research Assistant.
Use of inorganic amendments in golf course turf management is increasing. These amendments are used as either: 1) an additional component, or partial alternative to sand, in the sand-peat mixture in excavated-type greens; or 2) an alternative to sand in topdressing and core aerification. In the first case, the amendment generally replaces no more than $10 \%$ of the total volume of the sand-based mixture. Use of inorganic amendments in urban landscaping is also increasing. The purported benefits of these amendments, according to manufacturers, include plant pathogen sanitation, resistance to decomposition, and a greater porosity relative to that of sand. Depending upon the particular amendment, the CEC can be nearly equivalent to or greater than that of peat (Wehtje et al., 2000).

Comprehensive reviews on inorganic soil amendments have been prepared by several authors (Daniel and Freeborg, 1979; Grunthal, 1996). Most are produced from three basic types of naturally occurring mineral deposits: 1) clays, including montmorillonite and attapulgite; 2) zeolites, which are composed predominately of the mineral clinoptilolite; and 3) diatomaceous earths, which are the siliceous skeletal remains of diatoms (Wehtje et al., 2000). Mined materials are screened to a narrow particle range, i.e., approximately equivalent to that of coarse sand $(0.5-1.0 \mathrm{~mm})$. Generally, the clay and diatomaceous earthbased products are fired (calcined) at 1500 to $1700{ }^{\circ} \mathrm{C}$ to render the particles stable. Zeolitebased amendments are generally not fired.

Published studies dealing with these inorganic soil amendments are limited, and most have focused upon using these amendments as supplements to pure sand. Miller (2000), in a greenhouse study, grew bermudagrass in sand-filled cups. After bermudagrass establishment, cores were removed and back-filled with several different inorganic amendments in a manner that simulated core-aerification. Sand amended in this manner contained up to $16 \%$ more transpirable water relative to the nontreated control. This, in turn, reduced drought stress symptoms. Nus and Brauen (1991) evaluated creeping bentgrass (Agrostis palustris Huds.) establishment on sand-based putting greens that had been amended with either sawdust, sphagnum peat, or gravel-sized clinoptilolite (zeolite). Clinoptilolite and peat were equally effective in improving creeping bentgrass establishment. Ferguson et al. (1986) and Ferguson and Pepper (1987) noted that germination and establishment of creeping bentgrass, as well as clipping yield and $\mathrm{N}$-use efficiency, were increased by supplementing sand with up to $10 \%$ clinoptilolite zeolites. It was noted that the clinoptilolite zeolites evaluated had a high degree of internal tunneling and high CEC. This allowed $\mathrm{NH}_{4}^{+}$ions to be sorbed and held in an environment possibly void of microbial-based denitrification, while allowing release of $\mathrm{N}$ into solution for uptake. Joo et al. (1998) evaluated the physical and chemical properties of sand-based mixtures when a series of inorganic amendments were included at $10 \%$ by volume. Depending upon amendment choice, CEC, water retention, and bulk density were positively affected. Bigelow et al. (2001) compared creeping bentgrass performance in pure sand vs. sand amended $10 \%$ by volume with either three inorganic amendments or sphagnum peat moss. All amendments were associated with more rapid creeping bentgrass establishment and root development, improved turf quality, greater water retention, and increased CEC relative to that of nonamended sand. Depending upon the specific parameter, the inorganic amendments resulted in a response either equivalent to or greater than sphagnum peat. And while these studies were limited to various amendmentsand scenarios, MacKown and Tucker (1985) reported that adding zeolite to a coarse-textured soil did reduce leaching of $\mathrm{NH}_{4}^{+}$by increasing the overall CEC.

These aforementioned studies establish that inorganic amendments can improve the pertinent physical and chemical properties and/or turfgrass performance compared with the typical sand-based mixtures. However, whether these amendments are beneficial in improving the agronomic properties of some native soils, as with push-up greens and urban landscape applications, has not been established. Thus, if these amendments are beneficial in enhancing soil productivity, they may have potential outside of golf course 
endeavors. The objective of this research was to determine if any of the selected inorganic amendments were beneficial if incorporated into a heavily eroded native soil.

\section{Materials and Methods}

General information. The subsurface argillic horizon of Piedmont soils is often exposed due to accelerated erosion and/or constructional excavation. The upper portion of the argillic horizon of a Cecil soil (fine, kaolinitic, thermic Typic Kanhapludults) was collected for this study. The soil was air dried, lightly crushed, and passed through a $2-\mathrm{mm}$ screen. The soil was composed of $503 \mathrm{~g} \cdot \mathrm{kg}^{-1}$ clay, and 356 $\mathrm{g} \cdot \mathrm{kg}^{-1}$ sand. The clay fraction was dominated by kaolinite, hydroxy-interlayered vermiculite, with lesser amounts of gibbsite and Fe oxides. The low activity nature of the clay minerals results in a low CEC $\left(7.7 \mathrm{cmol} \cdot \mathrm{kg}^{-1}\right.$ soil).

Four inorganic amendments were included: Axis (Eagle-Picher Minerals, Reno, Nev.), Clinolite (Scientific Turf Products, Burnet, Texas), Green's Choice (Premier Environmental Products, Houston) and Profile (Applied Industrial Materials Corp., Buffalo Grove, Ill.). Axis is a nonfired diatomaceous earth primarily composed of poorly crystalline $\mathrm{SiO}_{2}$. Clinolite is a zeolitic material composed of the mineral clinoptilolite. Green's Choice is composed primarily of crystalline $\mathrm{SiO}_{2}$, while Profile is a fired clay. Amendment properties, including particle size distribution, surface area determinations, CEC, water-holding capacity, particle density, and electron micrographs of particle surface, have been previously reported (Wehtje et al., 2000). A coarse sand that meets all USGA putting green specifications (USGA Greens Section Staff, 1993) was included as a fifth amendment. According to laboratory analysis (Tifton Physical Soil Testing Laboratory, Tifton, Ga.), total "fines," i.e., particles $<0.05 \mathrm{~mm}$ in diameter, constituted $7.3 \%$ by weight; $75.6 \%$ were in the 0.5 - to $0.75-\mathrm{mm}$ range.

Experimental procedures. Soil-amendment mixtures were prepared such that the amend-

Table 1. $\mathrm{pH}$ and cation exchange capacity of the soil-amendment mixtures. ${ }^{2}$

\begin{tabular}{|c|c|c|c|c|c|}
\hline \multirow[b]{2}{*}{ Amendment } & \multicolumn{5}{|c|}{ Ratio of amendment to soil (v/v) } \\
\hline & 20 & 40 & 60 & 80 & 100 \\
\hline & & & $\mathrm{pH}-$ & & - \\
\hline Axis & 5.1 & 5.2 & 5.2 & 5.3 & 5.6 \\
\hline Clinolite & 5.1 & 5.1 & 5.2 & 5.6 & 7.4 \\
\hline Green's Choice & 5.3 & 5.7 & 6.3 & 7.3 & 8.7 \\
\hline Profile & 5.1 & 5.3 & 5.3 & 5.6 & 5.9 \\
\hline Sand & 5.1 & 5.1 & 5.2 & 5.4 & 5.5 \\
\hline & 7.01 & & $\mathrm{ol} \cdot \mathrm{kg}^{-1}$ & 822 & 6.70 \\
\hline Clinolite & $\begin{array}{r}1.01 \\
16.62\end{array}$ & 21.74 & $\begin{array}{l}10.41 \\
33.85\end{array}$ & $\begin{array}{r}0.22 \\
42.01\end{array}$ & 49.49 \\
\hline Green's Choice & 5.87 & 4.69 & 3.73 & 2.20 & 1.20 \\
\hline Profile & 8.67 & 8.93 & 10.16 & 10.68 & 10.47 \\
\hline Sand & 5.07 & 3.62 & 2.64 & 0.90 & 0.09 \\
\hline
\end{tabular}

${ }^{{ } \text {Measurement taken on two random grab samples collected from the }}$ bulk soil-amendment mixtures. $\mathrm{pH}$ and cation exchange capacity of the nonamended soil was 5.1 and $6.79 \mathrm{cmol} \cdot \mathrm{kg}^{-1}$, respectively. Cumulative coefficient of variation across all treatments were $3.5 \%$ and $3.8 \%$ for these variables, respectively. ments represented either $20 \%, 40 \%, 60 \%, 80 \%$, and $100 \%$, respectively, of the total mixture on a v/v basis. Thus, the experiment consisted of a factorial arrangement of five amendments and five ratios, yielding 25 treatments. Soil alone, i.e., nonamended, was the final treatment. About $8 \mathrm{~L}$ of each soil-amendment mixture was prepared and mixed in a rotary cement mixer. A fresh supply of the soil-amendment mixtures was prepared for each of the three experimental repetitions as described below.

Two random grab samples were collected from the bulk preparation of soil-amendment mixtures for determination of $\mathrm{pH}$ (Table 1); CEC (Table 1); and soil water content at $33 \mathrm{kPa}$ (field capacity), and at $150 \mathrm{kPa}$ tension, i.e., permanent wilting point (Table 2). The $\mathrm{pH}$ of the mixtures was measured in a 1:1 w/v slurry (Soil Survey Investigations Staff, 1996). CEC was measured from the bulk preparations of the soilamendment mixtures using the $\mathrm{NH}_{4} \mathrm{OAC}(\mathrm{pH}$ 7) method (Soil Survey Investigations Staff, 1996). All soil-water content measurements were determined using pressure plate apparatus (Soil Survey Investigations Staff, 1996). From the soil-water content at 33 and $150 \mathrm{kPa}$ tension, the available water-holding capacity AWHC) of each soil-amendment mixture was determined by subtraction (Table 2).

Styrofoam cups $(1 \mathrm{~L})$, with the bottoms perforated for drainage, were filled with each of the soil-amendment mixture treatments. Filled cups were watered until water drained through cup perforations. This was repeated daily for 3 d. Additional materials were added to compensate for any settling. 'Tifway' bermudagrass (4-cm-diameter plugs) were collected from established turf at the Auburn Univ. Turfgrass Research Unit. Soil and root material was sliced off below the foliage with the intent of leaving only enough roots for reestablishment. A single plug was planted in each cup. Cups were maintained in a ventilated greenhouse that received only ambient light. Cups were irrigated every Monday, Wednesday, and Friday with 50
$\mathrm{mL}$ water per cup. A completely randomized experimental design with four replications was used. The entire experiment was repeated $3 \times$, with the first, second, and third experimental repetitions initiated in Aug. 2000, Mar. 2001, and Aug. 2001, respectively.

Each soil-amendment mixture was fertilized at day $7,16,27,45$, and 51 with a water-soluble fertilizer that contained 10.7, 4.2 and $3.2 \mathrm{~mol} \cdot \mathrm{kg}^{-1}$ of $\mathrm{N}, \mathrm{P}$, and $\mathrm{K}$, respectively. Micronutrients were also included. Nutrient application rates were $2.7,2.3$ and $2.2 \mathrm{~g} \cdot \mathrm{m}^{-2}$ for $\mathrm{N}$, $\mathrm{P}_{2} \mathrm{O}_{5}$, and $\mathrm{K}_{2} \mathrm{O}$, respectively. To ensure adequate fertility levels were maintained, tissue analyses (Mills and Jones, 1996) were performed on composited bermudagrass clippings taken from the $40 \%$ and $100 \%$ amendment ratios of the first trial. These analyses established that tissue $\mathrm{N}$ averaged $3.10 \pm 0.25 \mathrm{~g} \cdot \mathrm{g}^{-1}$ for $40 \%$ amendment, $2.79 \pm 0.23 \mathrm{~g} \cdot \mathrm{g}^{-1}$ for $100 \%$ amendment; tissue $\mathrm{P}$ averaged $0.30 \pm 0.04 \mathrm{~g} \cdot \mathrm{g}^{-1}$ for $40 \%$ amendment, $0.39 \pm 0.21 \mathrm{~g} \cdot \mathrm{g}^{-1}$ for $100 \%$ amendment; and tissue K averaged $1.96 \pm 0.30$ $\mathrm{g} \cdot \mathrm{g}^{-1}$ for $40 \%$ amendment, $1.92 \pm 0.37 \mathrm{~g} \cdot \mathrm{g}^{-1}$ for $100 \%$ amendment. These values are all within published sufficiency ranges (Mills and Jones, 1996). The samples were not normalized for $\mathrm{pH}$ to allow direct comparison of amendment mixtures with regard to inherent properties. Published bermudagrass turf $\mathrm{pH}$ tolerance ranges from 5.5 to 7.0 (McCarty, 2001). Although $\mathrm{pH}$ values of many of the soil-amendment mixtures were below the acceptable $\mathrm{pH}$ range (Table 1), tissue analyses showed $\mathrm{Ca}$ tissue levels to be within acceptable ranges. Calcium levels equaled $0.37 \pm 0.10 \mathrm{~g} \cdot \mathrm{g}^{-1}$ for $40 \%$ amendment, and $0.40 \pm 0.10 \mathrm{~g} \cdot \mathrm{g}^{-1}$ for $100 \%$ amendment. Our intent was to provide ample, if not luxurious, amounts of water and nutrients during bermudagrass establishment and early growth periods.

About $21 \mathrm{~d}$ after planting, bermudagrass was clipped with hand scissors to $\approx 1 \mathrm{~cm}$ above the soil surface. This procedure was repeated a minimum of at least $4 \times$ on a $10-d$ schedule.

Table 2. Soil water content at $33 \mathrm{kPa}$, i.e., field capacity (top); $150 \mathrm{kPa}$, i.e., permanent wilting (middle); and available water (bottom) of the soil-amendment mixtures. ${ }^{\mathrm{z}}$

\begin{tabular}{|c|c|c|c|c|c|}
\hline \multirow[b]{2}{*}{ Amendment } & \multicolumn{5}{|c|}{ Ratio of amendment to soil (v/v) } \\
\hline & 20 & 40 & 60 & 80 & 100 \\
\hline & \multicolumn{5}{|c|}{ 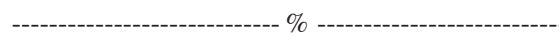 } \\
\hline Axis & 28.27 & 34.35 & 38.21 & 45.65 & 50.47 \\
\hline Clinolite & 23.30 & 22.55 & 22.18 & 17.34 & 14.88 \\
\hline Green's Choice & 21.64 & 21.96 & 18.96 & 19.82 & 17.83 \\
\hline Profile & 28.05 & 31.00 & 32.82 & 33.41 & 35.30 \\
\hline Sand & 17.37 & 12.59 & 10.40 & 7.61 & 3.32 \\
\hline Axis & 20.22 & 24.74 & 28.66 & 39.22 & 45.40 \\
\hline Clinolite & 16.08 & 15.75 & 15.21 & 14.57 & 14.45 \\
\hline Green's Choice & 15.11 & 14.28 & 12.62 & 11.25 & 12.02 \\
\hline Profile & 20.08 & 22.88 & 26.22 & 28.60 & 32.18 \\
\hline Sand & 11.98 & 9.22 & 6.09 & 2.66 & 0.71 \\
\hline Axis & 8.05 & 9.61 & 9.55 & 6.44 & 5.08 \\
\hline Clinolite & 7.22 & 6.80 & 6.97 & 2.77 & 0.43 \\
\hline Green's Choice & 6.53 & 7.68 & 6.34 & 8.57 & 5.80 \\
\hline Profile & 7.97 & 8.11 & 6.60 & 4.80 & 3.12 \\
\hline Sand & 5.39 & 3.38 & 4.31 & 4.95 & 2.61 \\
\hline
\end{tabular}

${ }^{\mathrm{z}}$ Measurement taken on two random grab samples collected from the bulk soil-amendment mixtures. Soil water content at $33 \mathrm{kPa}, 150 \mathrm{kPa}$, and available water of the nonamended soil was $20.89 \%, 15.98 \%$, and $4.91 \%$, respectively. Cumulative coefficient of variation across all treatments for soil water content at 33 and $150 \mathrm{kPa}$ was $2.4 \%$ and $1.4 \%$, respectively. 
Clippings were retained on an individual cup basis, dried at $50{ }^{\circ} \mathrm{C}$ for $24 \mathrm{~h}$, and weighed. At the completion of the final clipping, i.e., $\approx 30 \mathrm{~d}$ after planting, bermudagrass in some treatments had extended over the edge of the cups.

Irrigation was stopped after the final clipping. During the ensuing 30-d drought, growth eventually ceased and, depending upon the treatment, the grass eventually appeared dead. Irrigation as previously described was subsequently resumed, and a final clipping was taken 1 week later. Clipped tissue was visually separated into either green or desiccated and weighed. Percentage of total tissue that had been produced during the drought period that remained green and succulent with resumption of irrigation was then calculated.

Bulk density, soil strength, and oxygen diffusion rate (ODR) were determined on an individual experimental unit basis during the second experimental repetition of the bermudagrass performance experiment (Table 3). Soil strength was determined using a penetrometer (Pocket penetrometer model 29-5729, ELE International, Pelham, Ala.). Soil strength has been demonstrated to be highly dependent on soil water content (Busscher et al., 1997). Consequently, these measurements were taken $48 \mathrm{~h}$ after saturation ( $\approx$ field capacity), and again 23 d later (i.e., soil strength-dry). Meaningful differences between the individual soil-amendment mixtures were only evident after dry down; consequently, only these data are presented. However, both data sets were included in correlation procedures, as described below. Bulk density was determined by the procedures of Blake and Hartge (1986), after the completion of the second experimental repetition. The ODR was measured during the period of regular irrigations of the

Table 3. Bulk density, soil strength (dry) and oxygen diffusion rate of the soil-amendment mixtures. ${ }^{\mathrm{Z}}$

\begin{tabular}{|c|c|c|c|c|c|}
\hline \multirow[b]{2}{*}{ Amendment } & \multicolumn{5}{|c|}{ Ratio of amendment to soil $(\mathrm{v} / \mathrm{v})$} \\
\hline & 20 & 40 & 60 & 80 & 100 \\
\hline & & 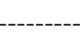 & $\mathrm{cm}^{-}$ & & \\
\hline Axis & $0.99^{* y}$ & $0.83^{*}$ & $0.72^{*}$ & $0.61^{*}$ & $0.41^{*}$ \\
\hline Clinolite & $1.07^{*}$ & $1.05^{*}$ & $1.01^{*}$ & $0.92^{*}$ & $0.84^{*}$ \\
\hline Green's Choice & $1.09^{*}$ & $1.01^{*}$ & $0.98^{*}$ & $0.93^{*}$ & $0.89^{*}$ \\
\hline Profile & $1.04^{*}$ & $0.97^{*}$ & $0.84^{*}$ & $0.76^{*}$ & $0.58^{*}$ \\
\hline Sand & 1.24 & 1.39 & 1.45 & 1.51 & 1.58 \\
\hline Axis & $2.44^{*}$ & $1.90^{*}$ & $\begin{array}{l}-\mathrm{mPa}- \\
1.75^{*}\end{array}$ & $1.58^{*}$ & $0.31^{*}$ \\
\hline Clinolite & 3.15 & 3.10 & 2.54 & $1.89^{*}$ & $0.29^{*}$ \\
\hline Green's Choice & 2.52 & 2.50 & $2.38^{*}$ & $1.33^{*}$ & $0.25^{*}$ \\
\hline Profile & 2.56 & $2.19^{*}$ & $1.92^{*}$ & $1.75^{*}$ & $0.25^{*}$ \\
\hline Sand & 2.58 & $2.31^{*}$ & $1.79^{*}$ & $1.15^{*}$ & $0.29^{*}$ \\
\hline Axis & 292 & 283 & $447^{* y}$ & $570^{*}$ & $747^{*}$ \\
\hline Clinoli & 300 & 326 & $440^{*}$ & $549^{*}$ & $721^{*}$ \\
\hline Green's Choice & 315 & 316 & $536^{*}$ & $588^{*}$ & $421^{*}$ \\
\hline Profile & 259 & 298 & $423^{*}$ & $508^{*}$ & $602^{*}$ \\
\hline Sand & 275 & 316 & 370 & 372 & $448^{*}$ \\
\hline
\end{tabular}

${ }^{\mathrm{z}}$ All data collected only from second experimental repetition. Response was influenced by the main effects of amendment, soil-amendment ratio, and by the interaction thereof. Bulk density, soil strength, and oxygen diffusion rate of the nonamended soil were $1.18 \mathrm{~g} \cdot \mathrm{cm}^{-3}, 2.88 \mathrm{mPa}$, and $305 \mu \mathrm{g} \cdot \mathrm{cm}^{-2} \cdot \mathrm{min}^{-1}$, respectively.

${ }^{{ }^{2} \mathrm{LSD}_{0.05}}$ between any two means $=0.07 \mathrm{~g} \cdot \mathrm{cm}^{-3}, 0.40 \mathrm{mPa}$, and $92 \mu \mathrm{g} \cdot \mathrm{cm}^{-2} \cdot \mathrm{min}^{-1}$, for these three variables respectively.

"Significance between this value and that of nonamended soil at $P \leq 0.05$. pooled across all amendments evaluated. Data from the nonamended soil were excluded.

\section{Results and Discussion}

Bermudagrass performance. Statistical analysis revealed that bermudagrass performance during the period of ample water and nutrients, as indicated by collected tissue weight from multiple clippings, varied between experimental repetitions. Consequently, these data are presented on an individual experimental repetition basis.

During the first experimental repetition, tissue production during luxurious watering was influenced by the amendment, the soilamendment ratio, and by their interaction (Table 4). In general, increasing amendment to soil ratio resulted in increased tissue production. Nonamended soil yielded $34 \mathrm{mg} \cdot \mathrm{cm}^{-2}$ of bermudagrass tissue after four clippings. This amount was significantly exceeded only by $100 \%$ Axis, $100 \%$ Green's Choice, and $80 \%$ and $100 \%$ sand. Conversely, all other soilamendment treatments were equivalent to nonamended soil with respect to promoting bermudagrass growth. Bermudagrass growth was not influenced by any of the experimental variables in the second experimental repetition (data not shown). In this repetition, nonamended soil yielded $73 \mathrm{mg} \cdot \mathrm{cm}^{-2}$ after four clippings, and all other treatments yielded an equivalent amount. In the third experimental repetition, bermudagrass growth was again influenced by the amendment, the soil-amendment ratio, and by their interaction (Table 4). Nonamended soil yielded $55 \mathrm{mg} \cdot \mathrm{cm}^{-2}$ across five clippings. This amount was exceeded by 17 of the soil-amendment mixtures. However, no clear pattern can be discerned as to which par-

Table 4. Total tissue produced in soil-amendment mixtures under luxurious water and nutrient in the first (top) and third (middle) experimental repetitions; and proportion of bermudagrass tissue produced during drought that became green and succulent with resumption of irrigation (bottom) as pooled over all experimental repetitions. ${ }^{\mathrm{z}}$

\begin{tabular}{|c|c|c|c|c|c|}
\hline \multirow[b]{2}{*}{ Amendment } & \multicolumn{5}{|c|}{ Ratio of amendment to soil (v/v) } \\
\hline & 20 & 40 & 60 & 80 & 100 \\
\hline & --- & 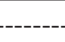 & $\mathrm{gg} \cdot \mathrm{cm}$ & - & --- \\
\hline Axis & 32 & 29 & 38 & 46 & $54^{* y}$ \\
\hline Clinolite & 29 & 35 & 38 & 42 & 42 \\
\hline Green's Choice & 28 & 31 & 32 & 42 & $49^{*}$ \\
\hline Profile & 42 & 42 & 46 & 38 & 42 \\
\hline Sand & 40 & 42 & 43 & $52^{* y}$ & $57^{*}$ \\
\hline Axis & 66 & $72^{* y}$ & 63 & $71^{*}$ & $82^{*}$ \\
\hline Clinolite & 65 & 68 & $86^{*}$ & $71^{*}$ & 49 \\
\hline Green's Choice & $78^{*}$ & $74^{*}$ & $83^{*}$ & $82^{*}$ & 52 \\
\hline Profile & $78^{*}$ & $86^{*}$ & $98^{*}$ & $80^{*}$ & $83^{*}$ \\
\hline Sand & 65 & 68 & $75^{*}$ & $69^{*}$ & $74^{*}$ \\
\hline Axis & 4 & 19 & $34^{* y}$ & $46^{*}$ & $53^{*}$ \\
\hline Clinolite & 5 & 10 & 12 & 18 & $26^{*}$ \\
\hline Green's Choice & 2 & 2 & 7 & 12 & $49^{*}$ \\
\hline Profile & 4 & $28^{*}$ & $46^{*}$ & $27^{*}$ & $59^{*}$ \\
\hline Sand & 0 & 0 & 0 & 10 & 0 \\
\hline
\end{tabular}

${ }^{\mathrm{z}}$ All response variables were influenced by the main effects of amendment, soil-amendment ratio, and by the interaction thereof. Comparable values for nonamended soil were $34 \mathrm{mg} \cdot \mathrm{cm}^{-2}$ (top), $53 \mathrm{mg} \cdot \mathrm{cm}^{-2}$ (middle) and $2 \%$ (bottom).

${ }^{\mathrm{y}} \mathrm{LSD}_{0.05}$ between any two means $=14 \mathrm{mg} \cdot \mathrm{cm}^{-2}$ (top), $16 \mathrm{mg} \cdot \mathrm{cm}^{-2}$ (middle), and $21 \%$ (bottom).

${ }^{*}$ Significance between this value and that of nonamended soil at $P \leq 0.05$. 
ticular soil-amendment treatments resulted in superior growth. The average amount of tissue collected from the nonamended soil across the three experimental repetitions during the period of ample water and nutrients were 8.5, 13.3, and $11.0 \mathrm{mg} \cdot \mathrm{cm}^{-2}$ per clipping, respectively. As previously mentioned, the three repetitions were conducted in Aug. 2000, Mar. 2001, and Aug. 2001, respectively. Night temperatures were never inhibitory to bermudagrass growth, i.e., below $20{ }^{\circ} \mathrm{C}$. However, daily maximums occasionally exceeded $38{ }^{\circ} \mathrm{C}$ during the two repetitions conducted in August. We attribute the lower yields in these two repetitions to transitory temperature stress in conjunction with decreasing day length.

Across all three experimental repetitions, no consistent trend was observed. No particular soil-amendment treatment(s) consistently resulted in superior bermudagrass growth compared to soil alone. Consequently, soil-amendment mixtures offered no clear improvement over soil alone when both water and nutrients were luxuriant.

A clear separation between treatments became evident after the drought period. No treatment $\times$ experimental repetition interactions were detected. Consequently, these data were pooled across all three experimental repetitions for further analysis and presentation (Table 4). The proportion of drought-produced bermudagrass tissue that became green and succulent with resumption of irrigation was again influenced by the amendment, the soilamendment ratio, and by their interaction. Only $2 \%$ of the bermudagrass tissue returned to succulence in nonamended soil. This percentage was exceeded by all treatments that contained either a minimum of $60 \%$ Axis or $40 \%$ Profile; and by $100 \%$ Clinolite and $100 \%$ Green's Choice.

Our results are in partial agreement with those obtained by Ralston and Daniel (1973). These researchers evaluated the performance of creeping bentgrass (Agrostis palustris Huds) under putting green condition in plots that contained either dune sand, mortar sand, calcined clay, diatomaceous earth, or native soil. Combination of these materials and soil were not included. Drought tolerance was frequently greater with the nonsoil materials, and this was attributed to enhanced water retention relative to native soil. While we also observed greater drought tolerance of bermudagrass in several of the amendments and soil-amendment mixtures, a clear relationship to water-holding abilities was not apparent.

Bermudagrass performance and chemical/ physical parameters; comparisons among individual treatments. Attempting to relate the drought-sustaining ability of these particular aforementioned treatments to any one physical/ chemical property was difficult. The obvious assumption was that these treatments simply retained more available water than soil alone. While examination of individual treatment means reveals no such relationship, significant correlations were detected in data that had been pooled across all soil-amendment treatments.

The field capacity (soil water content at 33 $\mathrm{kPa}$ ) of nonamended soil was $20.89 \%$ (Table 2). Comparable values among the drought-sustaining treatments ranged from 14.88 (100\% Clinolite) to 50.47 (100\% Axis). Available water of the nonamended soil was $4.91 \%$. Comparable values among the drought-sustaining treatments ranged from $0.43 \%$ (100\% Clinolite) to $9.55 \%$ (60\% Axis). Thus, the drought-sustaining treatments did not consistently have a greater soil water content at field capacity nor a greater available water content relative to that of nonamended soil.

All the soil-amendment mixtures that contained at least $20 \%$ of any of the amendments except sand had a lower bulk density than nonamended soil alone, i.e., $1.18 \mathrm{~g} \cdot \mathrm{cm}^{-3}$ (Table 3). All of the drought-sustaining treatments had significantly lower soil strength than nonamended soil, i.e., $2.88 \mathrm{mPa}$ (Table 3). Soil strength-dry of these treatments did not exceed $2.19 \mathrm{mPa}$, compared to that of nonamended soil at $2.88 \mathrm{mPa}$. However, other soil-amendment treatments, with equally reduced soil strength (notably those that contained sand), were not able to sustain bermudagrass growth during the drought.

All the drought-sustaining treatments except $40 \%$ Profile had a significant greater ODR than nonamended soil, i.e., $305 \mu \mathrm{g} \cdot \mathrm{cm}^{-2} \cdot \mathrm{min}^{-1}$ (Table 3). Other soil-amendment treatments also had significantly increased ODR relative to soil alone, but were not able to sustain bermudagrass growth during drought. Inspection of the data reveal that the most common physical attribute among the drought-sustaining treatments was a reduction in both bulk density and soil strength-dry, combined with an increase in ODR (Tables 3 and 4).

Bermudagrass performance and chemical/ physical parameters; correlations across all treatments. During the pre-drought period, when both water and nutrients were ample, total bermudagrass clipping weights were negatively $(P<0.05)$ correlated with both $\mathrm{pH}$ $(\mathrm{r}=-0.41)$ and CEC $(\mathrm{r}=-0.42)$ (Table 5). It is unclear why amendment mixtures with higher $\mathrm{pH}$ and higher CEC were associated with lower clipping weight. We speculate that the $\mathrm{pH}$ effect may be due to micronutrient availability and/or bermudagrass tolerance to acidity. Total bermudagrass clipping weights were positively $(P<0.05)$ correlated to soil water content at $33(\mathrm{r}=0.46)$ and $150 \mathrm{kPa},(\mathrm{r}=0.42)$. This indicates that the water-holding properties were critical to bermudagrass performance in this study.

After drought, bermudagrass clipping weight was again positively $(P<0.01)$ correlated with soil water content at $33(\mathrm{r}=0.78)$ and $150 \mathrm{kPa}(\mathrm{r}=0.79)$ (Table 5). Clipping weight was also negatively $(P<0.05)$ correlated with bulk density, suggesting that higher bulk densities were more inhibitory to growth after the drought period than before. The percentage by weight of the post-drought bermudagrass clipping that remained green was also correlated $(P<0.05)$ with the soil water parameters, soil

Table 5. Linear correlation coefficients (top) and probability (bottom) between chemical and physical properties of the soil-amendment mixtures in toto and bermudagrass performance parameters. ${ }^{2}$

\begin{tabular}{|c|c|c|c|c|c|c|c|c|c|c|}
\hline $\begin{array}{l}\text { Response } \\
\text { variable }^{y}\end{array}$ & Ratio $^{x}$ & $\mathrm{pH}$ & CEC & $\begin{array}{c}\text { Soil } \\
\text { water } \\
33 \mathrm{kPa} \\
\end{array}$ & $\begin{array}{c}\text { Soil } \\
\text { water } \\
150 \mathrm{kPa} \\
\end{array}$ & $\begin{array}{c}\text { Available } \\
\text { soil } \\
\text { water } \\
\end{array}$ & $\begin{array}{c}\text { Soil } \\
\text { strength- } \\
\text { FC }\end{array}$ & $\begin{array}{l}\text { Soil } \\
\text { strength- } \\
\text { Dry }\end{array}$ & $\begin{array}{c}\text { Bulk } \\
\text { density }\end{array}$ & $\begin{array}{c}\text { Oxygen } \\
\text { diffusion } \\
\text { rate }\end{array}$ \\
\hline \multicolumn{11}{|l|}{ Pre-drought } \\
\hline Clipping \#1 & $\begin{array}{l}0.26 \\
0.22\end{array}$ & $\begin{array}{l}0.04 \\
0.83\end{array}$ & $\begin{array}{r}-0.38 \\
0.06\end{array}$ & $\begin{array}{r}-0.06 \\
0.79\end{array}$ & $\begin{array}{r}-0.07 \\
0.74\end{array}$ & $\begin{array}{l}0.05 \\
0.80\end{array}$ & $\begin{array}{l}0.10 \\
0.62\end{array}$ & $\begin{array}{r}-0.35 \\
0.09\end{array}$ & $\begin{array}{l}0.21 \\
0.31\end{array}$ & $\begin{array}{r}-0.03 \\
0.88\end{array}$ \\
\hline $\begin{array}{l}\text { Clipping \#2 } \\
\text { Clipping \#3 }\end{array}$ & $\begin{array}{r}-0.20 \\
0.34 \\
-0.04 \\
0.85\end{array}$ & $\begin{array}{r}-0.41 \\
0.04 \\
-0.37 \\
0.07\end{array}$ & $\begin{array}{r}-0.74 \\
<0.01 \\
-0.07 \\
0.72\end{array}$ & $\begin{array}{r}-0.02 \\
0.92 \\
0.56 \\
<0.01\end{array}$ & $\begin{array}{r}-0.05 \\
0.81 \\
0.54 \\
0.01\end{array}$ & $\begin{array}{l}0.14 \\
0.51 \\
0.27 \\
0.19\end{array}$ & $\begin{array}{r}-0.07 \\
0.72 \\
0.22 \\
0.28\end{array}$ & $\begin{array}{r}-0.04 \\
0.83 \\
0.10 \\
0.62\end{array}$ & $\begin{array}{r}0.39 \\
0.05 \\
-0.39 \\
0.05\end{array}$ & $\begin{array}{r}-0.37 \\
0.07 \\
0.16 \\
0.45\end{array}$ \\
\hline Sum \#1-\#3 & $\begin{array}{r}-0.06 \\
0.78\end{array}$ & $\begin{array}{r}-0.41 \\
0.04\end{array}$ & $\begin{array}{r}-0.42 \\
0.04\end{array}$ & $\begin{array}{l}0.46 \\
0.02\end{array}$ & $\begin{array}{l}0.42 \\
0.03\end{array}$ & $\begin{array}{l}0.32 \\
0.12\end{array}$ & $\begin{array}{l}0.19 \\
0.36\end{array}$ & $\begin{array}{l}0.02 \\
0.91\end{array}$ & $\begin{array}{r}-0.17 \\
0.42\end{array}$ & $\begin{array}{r}-0.02 \\
0.91\end{array}$ \\
\hline \multicolumn{11}{|l|}{ Post-drought } \\
\hline Clipping \#4 & $\begin{array}{l}0.08 \\
0.70\end{array}$ & $\begin{array}{r}-0.14 \\
0.50\end{array}$ & $\begin{array}{l}0.02 \\
0.91\end{array}$ & $\begin{array}{r}0.78 \\
<0.01\end{array}$ & $\begin{array}{r}0.79 \\
<0.01\end{array}$ & $\begin{array}{l}0.20 \\
0.33\end{array}$ & $\begin{array}{l}0.44 \\
0.03\end{array}$ & $\begin{array}{r}-0.12 \\
0.56\end{array}$ & $\begin{array}{l}-0.72 \\
<0.01\end{array}$ & $\begin{array}{l}0.19 \\
0.37\end{array}$ \\
\hline$\%$ Green-\#4 & $\begin{array}{r}0.61 \\
<0.01\end{array}$ & $\begin{array}{l}0.34 \\
0.10\end{array}$ & $\begin{array}{l}0.08 \\
0.71\end{array}$ & $\begin{array}{r}0.67 \\
<0.01\end{array}$ & $\begin{array}{r}0.74 \\
<0.01\end{array}$ & $\begin{array}{r}-0.08 \\
0.70\end{array}$ & $\begin{array}{l}0.37 \\
0.07\end{array}$ & $\begin{array}{l}-0.59 \\
<0.01\end{array}$ & $\begin{array}{l}-0.78 \\
<0.01\end{array}$ & $\begin{array}{r}0.59 \\
<0.01\end{array}$ \\
\hline
\end{tabular}

${ }^{2}$ Data pooled over all three experimental repetitions.

${ }^{y}$ Clippings \#1-4 = bermudagrass weight (g) collected. \% Green = percentage of clipping \#4 that had became green and succulent with irrigation resumption. ${ }^{x}$ Ratio $=\% \mathrm{v} / \mathrm{v}$ of amendment to soil; CEC $=$ cation exchange capacity $\left(\mathrm{cmol} \cdot \mathrm{kg}^{-1}\right)$. Soil water $1 / 3 \mathrm{bar}$ and 15 bar is gravimetric water content $(\%)$ at 33 and 150 $\mathrm{kPa}$, respectively. Soil strength-FC = penetrometer resistance at field capacity $(33 \mathrm{kPa})$. Soil strength-Dry is same measurement after dry down, i.e., gravimetric water content $=0.05 \% \pm 0.03 \%$. Bulk density expressed as $\mathrm{g} \cdot \mathrm{cm}^{-3}$ and oxygen diffusion rate as $\mu \mathrm{g} \cdot \mathrm{cm}^{-2} \cdot \mathrm{min}^{-1}$. 
strength, bulk density, and ODR. Conversely, no correlation at $P<0.05$ was detected between green tissue, $\mathrm{pH}$, and CEC.

In summary, data presented indicate that improvement in bermudagrass performance in soil-amendment mixtures relative to soil alone is most likely related to increased waterholding capacity, and the interrelated physical properties of bulk density, soil strength, and ODR. Conversely, alteration of soil chemical properties, such as $\mathrm{pH}$ and $\mathrm{CEC}$, were of lesser importance in this study. The merits of incorporating these amendments into soil was increasingly manifested during the drought. Our data suggest the amount required for a significant improvement over that of soil alone was $\geq 40 \%$, and that improvement was somewhat amendment dependent.

\section{Literature Cited}

Ball, B.C. and K.A. Smith. 1991. Gas movement and air-filled porosity, p. 511-550. In: K.A. Smith and C.E. Mullins (eds.). Soil analysis: Physical methods. Marcel Dekker, New York.

Bigelow, C.A., D.C. Bowman, D.K. Cassel, and T.W. Rufty, Jr. 2001. Creeping bentgrassresponse to inorganic soil amendments and mechanically induced subsurface drainage and aeration. Crop Sci. 41:797-805.

Blackwell, P.S. 1983. Measurements of aeration in waterlogged soils: Some improvements of techniques and the application to experiments using lysimeters. J. Soil. Sci 34:271-285.

Blake, G.R. and K.H. Hartge. 1986. Bulk density, p. 363-376. In: A. Klute (ed.). Methods of soil analysis. Part 1.2nd ed. Agron. Monogr. 9. ASA and SSSA, Madison, Wis.

Busscher, W.J., P.J. Bauer, C.R. Camp, and R.E. Sojka. 1997. Correction of cone index for soil water content differences in a coastal plain soil. Soil Tillage Res. 43:205-217.

Christians, N. 1998. Fundamentals of turfgrass management. 1st ed. Ann Arbor Press, Chelsea, Mich.

Daniel,W.H. and R.P. Freeborg. 1979. Rootzones and water, p. 137-199. In: Turf managers' handbook. Harvest Publ., Cleveland, Ohio.

Ferguson, G.A. and I.L.. Pepper. 1987. Ammonium retention in sand amended with clinoptilolite. Soil Sci. Soc. Amer. J. 51:231-234.

Ferguson, G.A., I.L. Pepper, and W.R. Kneebone. 1986. Growth of creeping bentgrass on a new medium for turfgrass growth: Clinoptilolite zeolite-amended sand. Agron. J. 78: 1095-1098.

Grunthal, P.E. 1996. Buried treasure: The "dirt" on inorganic soil amendments to enhance turfgrass. GreenMaster. June/July.

Joo, Y.K., N.E. Christian, D. Li, and D.D. Minner. 1998. Effects of soil amendments on the chemical and physical soil parameters of a sand-based golf green. 1998 Iowa Turfgrass Res. Rpt. Available online (May 2002) at: http:// www.hort.iastate.edu/pages/news/turfrpt/1998.

Kussow, W.R. 1987. Peats in greens: Knowns, unknowns, and speculations. USGA Greens Section Record 25(5):5-7.

MacKown, C.T. and T.C, Tucker. 1985. Ammonium nitrogen movement in a coarse-textured soil amended with zeolite. Soil Sci. Soc. Amer. J. 49:235-238.

McCarty, L.B. 2001. Best golf course management practices. Prentice-Hall, Upper Saddle River, N.J.

Miller, G.L. 2000. Physiological response of bermudagrass grown in soil amendment during drought stress. HortScience 35:213-216.

Mills, H.A. and J.B. Jones, Jr. 1996. Plant analysis handbook II. Micro Macro Publ., Jefferson City, Mo.

Nus, J.L. and S.E. Brauen. 1991. Clinoptilolite zeolite as an amendment for the establishment of creeping bentgrass on sand media. HortScience 26:117-119.

Ralston, D.S. and W.H. Daniel. 1973. Effect of porous rootzone materials underlined with plastic on the growth of creeping bentgrass. Agron. J. 65:229-232.

Soil Survey Investigation Staff. 1996. Soil survey laboratory methods manual. Soil Surv. Inv. Rpt. 42. USDA-SCS, Natl. Soil Survey Ctr., Lincoln, Nebr.

U.S. Golf Association Greens Section Staff. 1993. Recommendations for a method of putting green construction. USGA Green Section Record 31(2):1-3.

Wehtje, G., R.H. Walker, and J.N. Shaw. 2000. Pesticide retention by inorganic soil amendments. Weed Sci. 48:248-254. 